Prepared in Cooperation with the North Platte Natural Resource District, South Platte Natural Resource District, and the Nebraska Environmental Trust

\title{
Helicopter Electromagnetic and Magnetic Geophysical Survey Data for Portions of the North Platte River and Lodgepole Creek, Nebraska, June 2008
}

By Bruce D. Smith, Jared ' . Abraham, James C. Cannia, and Patricia Hill

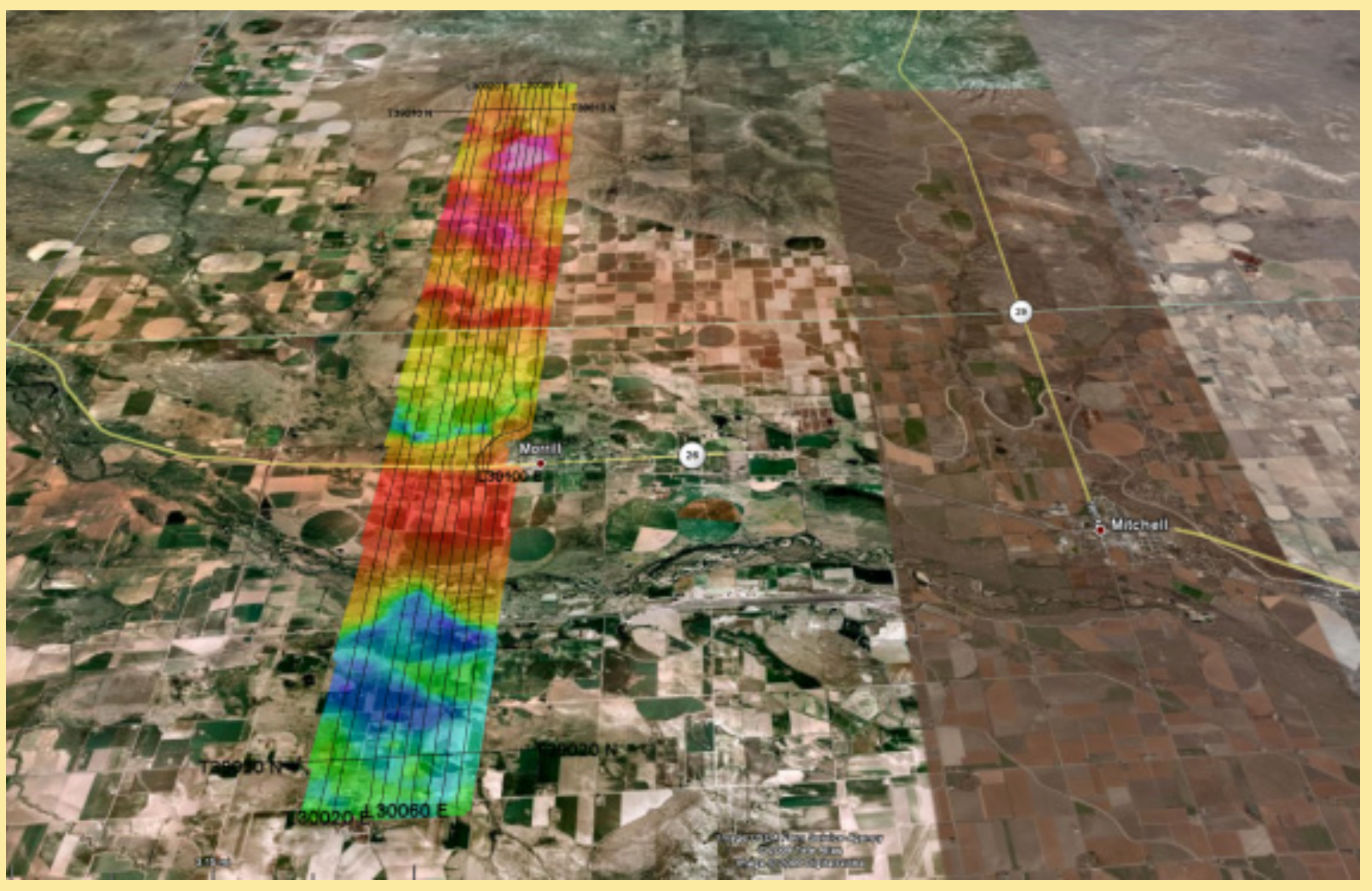

Open-File Report 2009-1110

Version 1.0

U.S. Department of the Interior

U.S. Geological Survey 


\title{
U.S. Department of the Interior \\ KEN SALAZAR, Secretary
}

\author{
U.S. Geological Survey \\ Marcia K. McNutt, Director
}

U.S. Geological Survey, Reston, Virginia: 2009

For product and ordering information:
World Wide Web: http://www.usgs.gov/pubprod/
Telephone: 1-888-ASK-USGS

For more information on the USGS-the Federal source for science about the Earth, its natural and living resources, natural hazards, and the environment:

World Wide Web: http://www.usgs.gov/

Telephone: 1-888-ASK-USGS

$\square$

[

[?

[

Suggested citation:

Smith, B.D., Abraham, J.' ., Cannia, J.C., and Hill, P.L., 2009, Helicopter electromagnetic and magnetic geophysical survey data for portions of the North Platte River and Lodgepole Creek, Nebraska, April 2008: U.S. Geological Survey Open-File Report 2009-1110, 34 p.

Any use of trade, product, or firm names is for descriptive purposes only and does not imply endorsement by the U.S. Government.

Although this report is in the public domain, permission must be secured from the individual copyright owners to reproduce any copyrighted material contained within this report.

Front Cover: Google Earth view of apparent resistivity map for the North Platte Morrill flight block looking north. Dark lines are the flight path of the helicopter. Warm colors are high values and cooler (blues) are low values of apparent resistivity. 


\section{Contents}

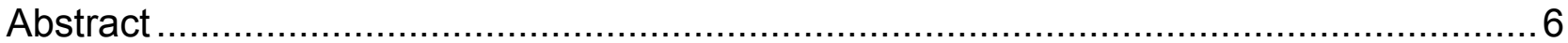

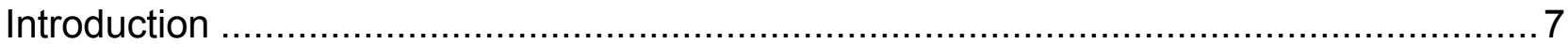

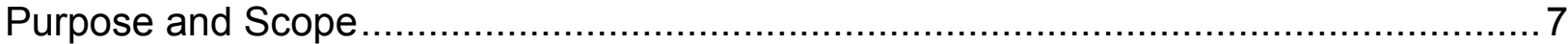

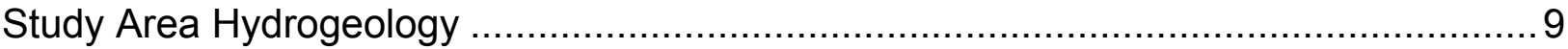

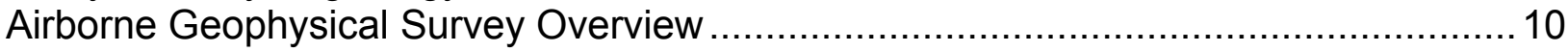

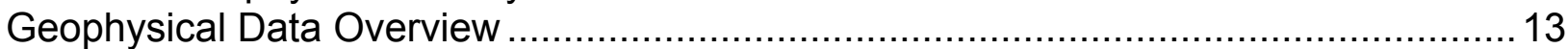

Helicopter Electromagnetic and Magnetic Survey .................................................... 14

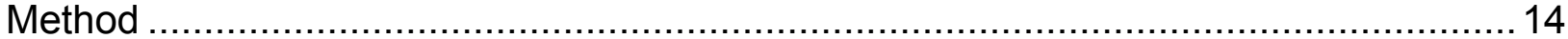

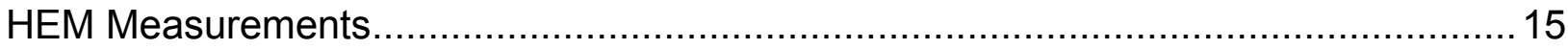

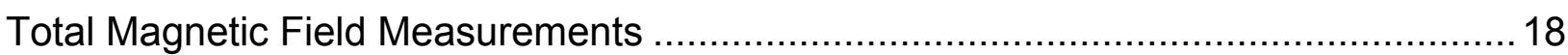

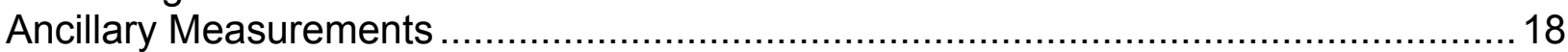

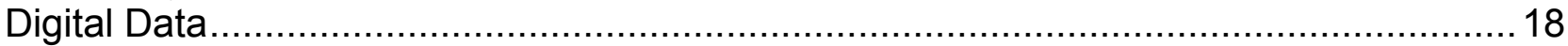

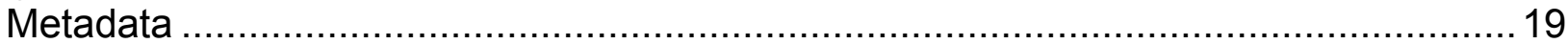

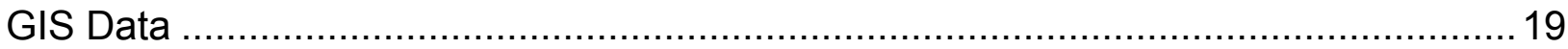

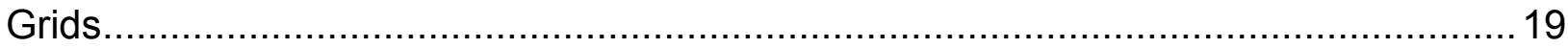

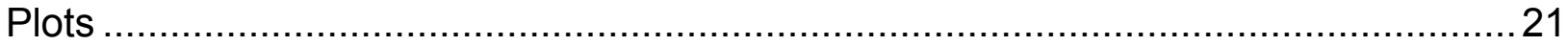

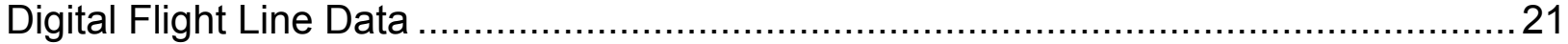

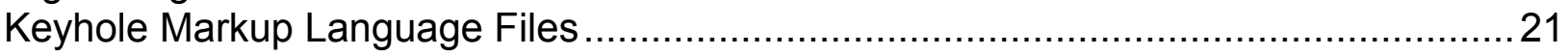

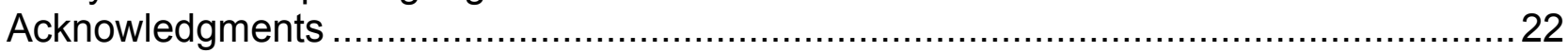

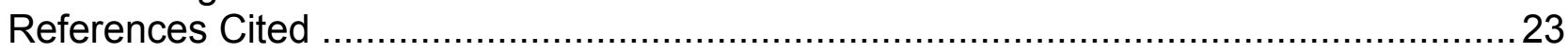

Appendix I: American Geophysical Union Poster ................................................2 23

Appendix 2: Fugro Airborne Ltd. Geophysical Report ...........................................2

\section{Figures}

\section{1-6 Figures showing:}

Figure 1. Location of study area and helicopter electromagnetic and magnetic survey flight lines. The airborne survey was designed to provide supplemental data to the Cooperative Hydrologic Study (COHYST) groundwater model and to the NPNRD groundwater model.

Figure 2. Hydrogeologic units in the HEM survey area (adapted from Cannia and others, 2006). In general silts, shales, and siltstones tend to be electrically conductive or to have low resistivity. Dune sands, sandstones, and gravels tend to be electrically resistive.

Figure 3. Detailed location maps for HEM survey areas: A) location map for the North Platte River survey and, B) location map for the Lodgepole Creek survey area (adapted from Fugro Airborne, Ltd. report in Appendix 2).

Figure 4. Helicopter-borne RESOLVE@ geophysical system similar that used in the Nebraska survey: Electromagnetic, magnetic, GPS and laser altimeter sensors are housed in a "bird", a cigar-shaped $9 \mathrm{~m}$ long tube, which is kept at about $30-40 \mathrm{~m}$ above ground level. Additional altimeters and the navigation system are installed in the helicopter. The base station records the total magnetic field variations (diurnal) during the survey. 
Figure 5. Depth of penetration or imaging as a function of frequency and earth resistivity for the RESOLVE@ system (G. Hodges, Fugro Airborne Ltd., 2004, written comm.).

Frequencies, in hertz, are given for each colored line on the right.

Figure 6. Screenshot of ArcMap plot of GEOSOFT grid for the Morrill Block. Note the GEOSOFT plug-in is displayed in the toolbar. The background topographic relief map is displayed using data added by internet servers. The display in the lower right shows the projection tool that might be needed to properly define the projection of the grid.

Figure 7. Screen capture of a Google Earth map for the HEM survey in Sidney, Nebraska, area. The data shown is the apparent resistivity map at $40,000 \mathrm{~Hz}$. Black lines are flight lines with selected flight line numbers shown. Note that in the panel on the left of the display, various layers can be turned on and off and their transparency adjusted.

\section{Tables}

Table 1. Digital data organization and description of files and directories 13

Table 2. Flight line direction and spacing for each survey area. Flight lines are numbered according to block. For example block 1 flight lines are numbered 10010, 10020, and so on.

Table 3. Frequencies and measurement sensitivities for the HEM survey. The coil pair separation is 7.9 meters for all except for the $3300 \mathrm{~Hz}$ coil-pair which is 9.0 meters.

\section{Conversion Factors, Datum, and Acronyms}

\section{SI to Inch/Pound}

\begin{tabular}{lcl}
\hline \multicolumn{1}{c}{ Multiply } & \multicolumn{1}{c}{ By } & \multicolumn{1}{c}{ To obtain } \\
\hline meter $(\mathrm{m})$ & 3.281 & foot $(\mathrm{ft})$ \\
kilometer $(\mathrm{km})$ & 0.6214 & mile $(\mathrm{mi})$ \\
square kilometer $\left(\mathrm{km}^{2}\right)$ & 247.1 & acre \\
liter $(\mathrm{L})$ & 0.2642 & gallon $(\mathrm{gal})$ \\
nanotesla $(\mathrm{nT})$ & 1 & gamma \\
gram $(\mathrm{g})$ & 0.03527 & ounce, avoirdupois $(\mathrm{oz})$ \\
\hline
\end{tabular}

Temperature in degrees Celsius $\left({ }^{\circ} \mathrm{C}\right)$ may be converted to degrees Fahrenheit $\left({ }^{\circ} \mathrm{F}\right)$ as follows:

${ }^{\circ} \mathrm{F}=\left(1.8 \times{ }^{\circ} \mathrm{C}\right)+32$.

Electrical conductivity is given in millisiemens per meter $(\mathrm{mS} / \mathrm{m})$ unless otherwise specified Electrical resistivity is given in ohm meters unless otherwise specified.

$1 \mathrm{mS} / \mathrm{m}=1000 /$ (1ohm meter) thus $10 \mathrm{mS} / \mathrm{m}=100$ ohm meters.

Vertical coordinate information is referenced to the "North American Vertical Datum of 1988 (NAVD 88)" except as noted in text. 
Horizontal coordinate information is referenced to the "North American Datum of 1984, Universal Transverse Mercator Zone 13 (NAD 84 UTM Zone 13N)" except as noted in text.

Airborne geophysical survey reference for GPS data is WGS84 as explained in the text.

Main text gives description of data projections used in acquisition and processing.

ACRONYMS USED IN THIS REPORT:

EM Electromagnetic

DTM Digital Terrain Model

GPS Global Positioning System

HEM Helicopter Electromagnetic

RTP Reduced-to-Pole

USGS U.S. Geological Survey

UTM Universal Transverse Mercator

ABBREVIATIONS USED IN THIS REPORT:

$\mathrm{Hz} \quad$ hertz

$\mathrm{kHz} \quad$ kilohertz 


\title{
Helicopter Electromagnetic and Magnetic Geophysical Survey Data for Portions of the North Platte River and Lodgepole Creek, Nebraska, June 2008
}

\author{
By Bruce D. Smith, Jared D. Abraham, James C. Cannia, and Patricia Hill
}

\begin{abstract}
This report is a release of digital data from a helicopter electromagnetic and magnetic survey that was conducted during June 2008 in areas of western Nebraska as part of a joint hydrologic study by the North Platte Natural Resource District, South Platte Natural Resource District, and U.S. Geological Survey. The objective of the contracted survey, conducted by Fugro Airborne, Ltd., was to improve the understanding of the relationship between surface water and groundwater systems critical to developing groundwater models used in management programs for water resources. The survey covered 1,375 line $\mathrm{km}$ (854 line $\mathrm{mi}$ ). A unique aspect of this survey is the flight line layout. One set of flight lines were flown paralleling each side of the east-west trending North Platte River and Lodgepole Creek. The survey also included widely separated (10 km) perpendicular north-south lines. The success of this survey design depended on a well understood regional hydrogeologic framework and model developed by the Cooperative Hydrologic Study of the Platte River Basin. Resistivity variations along lines could be related to this framework. In addition to these lines, more traditional surveys consisting of parallel flight lines separated by about $270 \mathrm{~m}$ were carried out for one block in each of the drainages. These surveys helped to establish the spatial variations of the resistivity of hydrostratigraphic units.

The electromagnetic equipment consisted of six different coil-pair orientations that measured resistivity at separated frequencies from about $400 \mathrm{~Hz}$ to about $140,000 \mathrm{~Hz}$. The electromagnetic data along flight lines were converted to electrical resistivity. The resulting line data were converted to geo-referenced grids and maps which are included with this report. In addition to the electromagnetic data, total field magnetic data and digital elevation data were collected. Data released in this report consist of data along flight lines, digital grids, and digital maps of the apparent resistivity and total magnetic field. The depth range of the subsurface investigation for the electromagnetic survey (estimated as deep as $60 \mathrm{~m}$ ) is comparable to the depth of shallow aquifers. The geophysical data and hydrologic information from U.S. Geological Survey and cooperator studies are being used by resource managers to develop groundwater resource plans for the area. In addition, data will be used to refine hydrologic models in western Nebraska.
\end{abstract}




\section{Introduction}

Airborne geophysical studies have been effectively used by the U.S. Geological Survey (USGS) in a variety of groundwater resource projects and programs (Smith and others, 2007). Electrical geophysical methods can be used to image the subsurface of the earth using techniques very similar to a medical CAT (computed axial tomography) scan of the human body (Won, 1990). A specific example is the helicopter electromagnetic (HEM) survey conducted for the USGS in the upper Missouri River Basin (Poplar, Montana) to study groundwater quality (Smith and others, 2006) in a similar hydrologic setting to parts of Nebraska. Based on the success of these and other groundwater studies using airborne geophysical methods (Smith and others, 2007), the USGS received funding from Nebraska state agencies to conduct subsurface airborne resistivity mapping in western Nebraska. The results from that project have been described by Cannia and others (2007). The HEM data for that project have been released as a USGS Open-File Report (Smith and others, 2008a). Based in part on this successful application of the HEM mapping method, funding was obtained to contract an airborne geophysical survey in the non-glaciated terrain of western Nebraska. This is a large, multi-faceted study requiring successful coordination and planning between multiple levels of government. Public involvement with funding of water resources studies at the local, state, and federal levels have been and will continue to be vital to long-term success in improving hydrologic settings and modeling.

The North Platte Natural Resource District (NPNRD) funded surveys of the North Platte River Basin from the Wyoming-Nebraska state line to approximately Bridgeport, Nebraska. The South Platte NRD (SPNRD) funded a survey of the Lodgepole Creek Basin. Figure 1 shows the general location of the HEM surveys and Figure 3 shows the specific location of flight lines described in this report. The contract was awarded to Fugro Airborne Ltd with technical specifications developed by the USGS. Contract monitoring and data quality assurance was carried out by the USGS. Fiscal management of the contract was by the NPNRD. The digital airborne geophysical data collected along flight lines was processed by the contractor to produce digital databases and digital maps. Additional data processing was done by the USGS and supplemental maps were produced. These digital line data and maps are also included as part of the digital data release.

\section{Purpose and Scope}

This report presents HEM and magnetic maps and data that were collected by Fugro Airborne Ltd. from June $15^{\text {th }}$ to $23^{\text {rd }}, 2008$, in western Nebraska (the panhandle). The survey flight lines consisted of 1375 line $\mathrm{km}$ (854 line mi). The objective of the survey was to improve the understanding of the relationship between surface water and groundwater systems critical to developing management programs for water resources. The airborne geophysical survey data can be used to map subsurface electrical and magnetic properties of the earth that can be related to geologic and hydrologic features. In particular, interpretation of the HEM data will be used to refine aquifer geometry for groundwater and geologic models in the western Platte River Basin. 
Survey flight lines in the western Nebraska panhandle, were designed to provide subsurface data to supplement groundwater models and drillhole information. Flight lines were flown along the North Platte River and Lodgepole Creek Valleys (Figure 1) and widely-spaced lines were flown in the North Platte River Valley perpendicular to the drainage. One block of north-south $270 \mathrm{~m}$ spaced lines was flown near the town of Morrill. A set of lines was also flown just west of the city of Sidney in the Sidney Draw area.

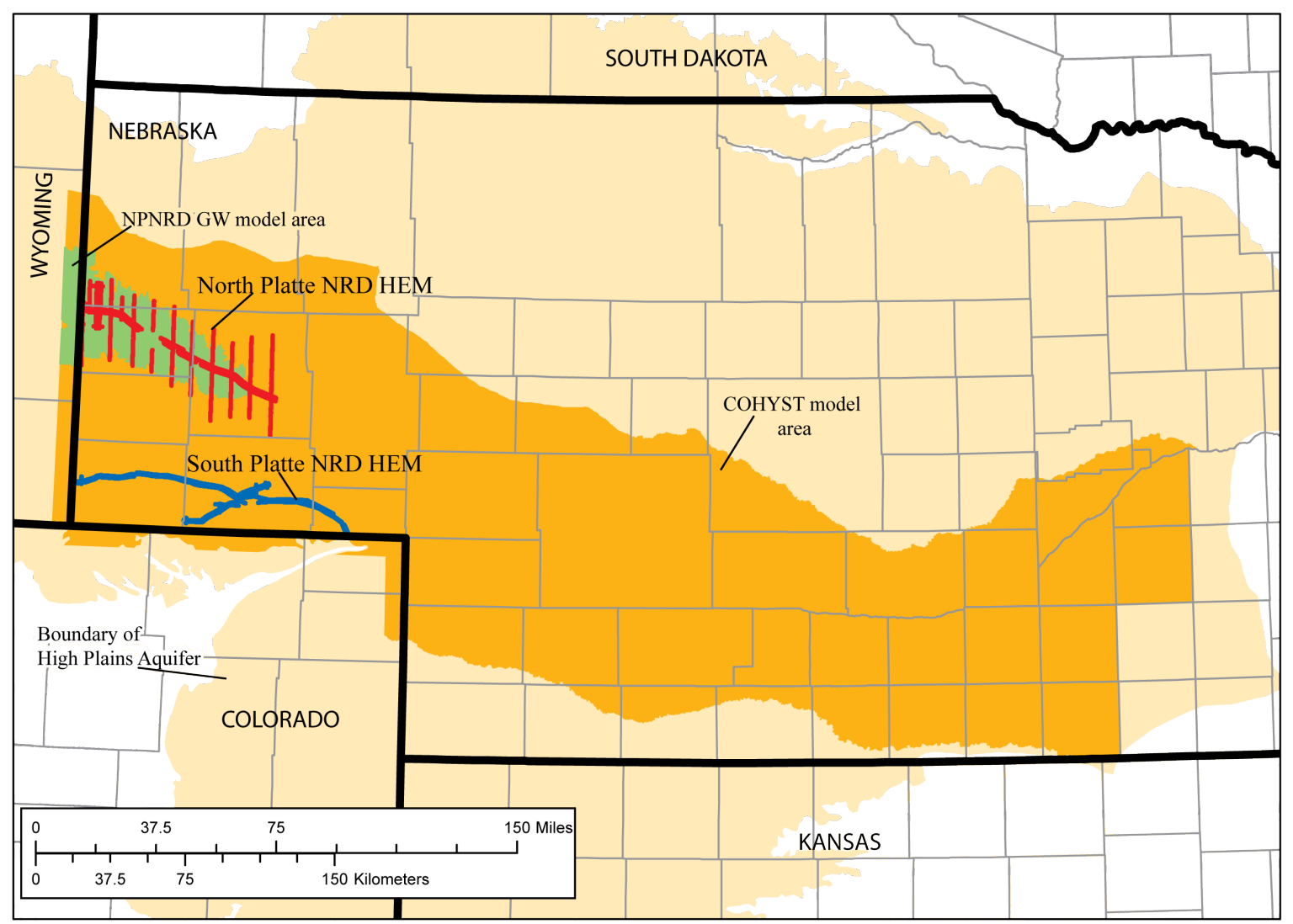

Figure 1. Location of study area and helicopter electromagnetic and magnetic survey flight lines. The airborne survey was designed to provide supplemental data to the Cooperative Hydrologic Study (COHYST) groundwater model and to the NPNRD groundwater model. 


\section{Study Area Hydrogeology}

The generalized geology for the study area consists of Quaternary alluvium, and interbedded Tertiary sandstones and siltstones above Cretaceous shale. The Quaternary alluvium comprises the primary aquifer in the North Platte River Valley, whereas thin alluvial sediments and Tertiary sandstone channels comprise the primary aquifers in Lodgepole Creek Valley. Locally, Tertiary siltstone and Cretaceous shale is weathered and incised.

The hydrogeology of the study area described by Cannia and others (2006) includes the High Plains aquifer (Weeks and others, 1988), which underlies nearly all of the study area and consists of parts of the Brule Formation, the Arikaree Group, the Ogallala Group, and Quaternary deposits (Figure 2).

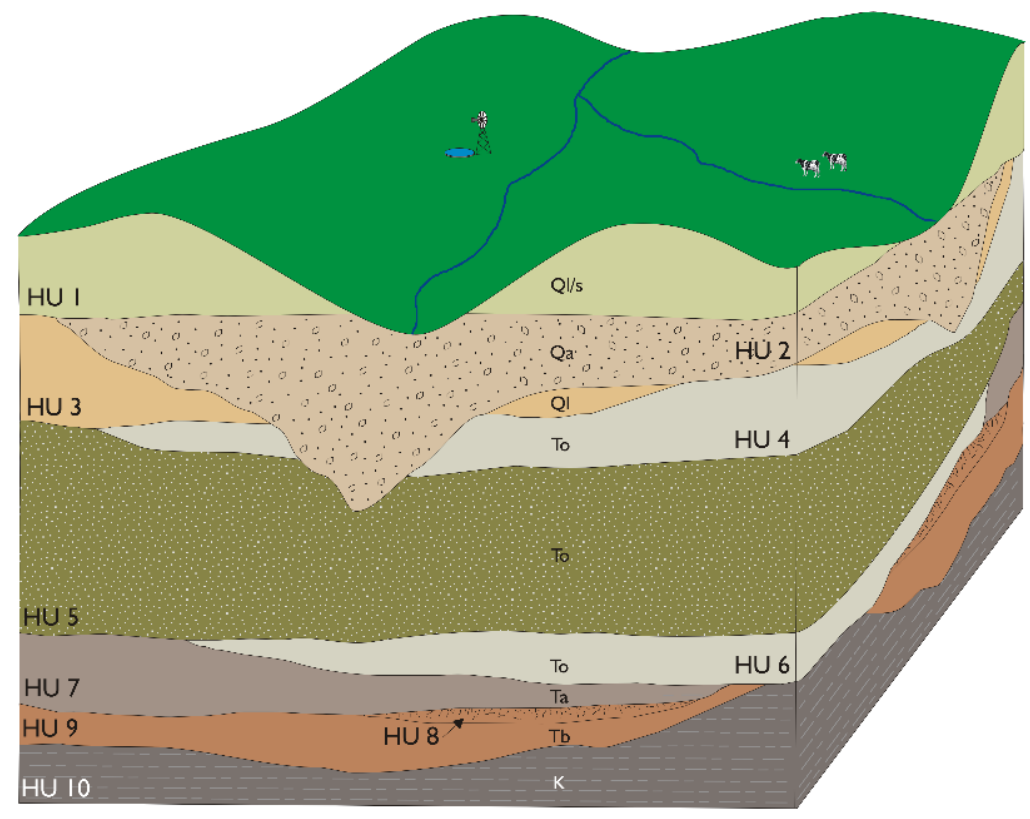

\begin{tabular}{|c|c|c|}
\hline & $\begin{array}{l}\text { ormation/Group } \\
\text { Description }\end{array}$ & $\begin{array}{c}\text { Hydrostratigraphic } \\
\text { Unit (HU) }\end{array}$ \\
\hline Q1/s & $\begin{array}{l}\text { Upper Quaternary Fines } \\
\text { (Loess or Dune Sand) }\end{array}$ & 1 \\
\hline $\mathrm{Qa}$ & $\begin{array}{l}\text { Quaternary Alluvial/ } \\
\text { Valley Fill Deposits }\end{array}$ & 2 \\
\hline$Q_{1}$ & $\begin{array}{l}\text { Lower Quaternary Fines } \\
\text { (Loess/Silt) }\end{array}$ & 3 \\
\hline To & $\begin{array}{l}\text { Tertiary Ogallala Group } \\
\text { Silts/Siltstones }\end{array}$ & 4,6 \\
\hline To & $\begin{array}{l}\text { Tertiary Ogallala Group } \\
\text { Sands/Sandstones }\end{array}$ & 5 \\
\hline $\mathrm{Ta}$ & $\begin{array}{l}\text { Tertiary Arikaree Group } \\
\text { Sandstones/Siltstones }\end{array}$ & 7 \\
\hline $\mathrm{T}_{\mathrm{T} \mathrm{b}^{\prime}}$ & $\begin{array}{l}\text { Tertiary White River Group } \\
\text { Fractured Brule Fm. Siltstones }\end{array}$ & 8 \\
\hline $\mathrm{Tb}$ & $\begin{array}{l}\text { Tertiary White River Group } \\
\text { Brule Fm. Siltstones/Sandstones }\end{array}$ & 9 \\
\hline K & $\begin{array}{l}\text { Undifferentiated Cretaceous } \\
\text { Units - (Base of Aquifer) }\end{array}$ & 10 \\
\hline
\end{tabular}

Figure 2. Hydrogeologic units in the HEM survey area (adapted from Cannia and others, 2006). In general silts, shales, and siltstones tend to be electrically conductive or to have low resistivity. Dune sands, sandstones, and gravels tend to be electrically resistive. 
The Lodgepole Creek part of the study area has been described by Steele and others (2007). The surficial aquifers are Quaternary-age alluvium along Lodgepole Creek and the Tertiary Ogallala Group and Brule Formation (figure 2). The three geologic units are separated by two major erosional unconformities. Lodgepole Creek is the predominant watercourse of the South Platte NRD. Flows are typically ephemeral or intermittent. The largest tributary to Lodgepole Creek, Sidney Draw is also an ephemeral drainage. Both drainages were investigated by the airborne geophysical survey described in this report.

\section{Airborne Geophysical Survey Overview}

The management and allocation of water resources in Nebraska is based in part on understanding the relation between surface water and groundwater systems. To help understand these complex relations, the USGS conducted airborne resistivity and magnetic (frequency domain HEM) surveys in eastern Nebraska in 2007 (Smith and others, 2008a) and western Nebraska 2008 (this report). These surveys were integrated with hydrologic studies (aquifer characteristics and modeling) and with ground and borehole geophysical surveys to characterize and map the hydrogeologic framework in three dimensions. The poster in Appendix 1 by Smith and others (2008b) gives an overview of the airborne electromagnetic surveys conducted in Nebraska for groundwater studies.

The airborne geophysical survey was structured in three main phases: (1) data acquisition and preliminary processing in the field, (2) final data processing conducted by the contractor (Fugro Airborne, Ltd.) and by the USGS, and (3) interpretation of the processed data including conversion of flight line data to resistivity depth sections. This report and the report by the contractor given in Appendix 2 address the first two phases of the project. The interpretative phase is ongoing and covered in separate publications and reports. A team of experts is needed to interpret the processed data in the context of hydrologic frameworks since this evaluation requires an understanding of geophysical methods and hydrogeologic setting. 


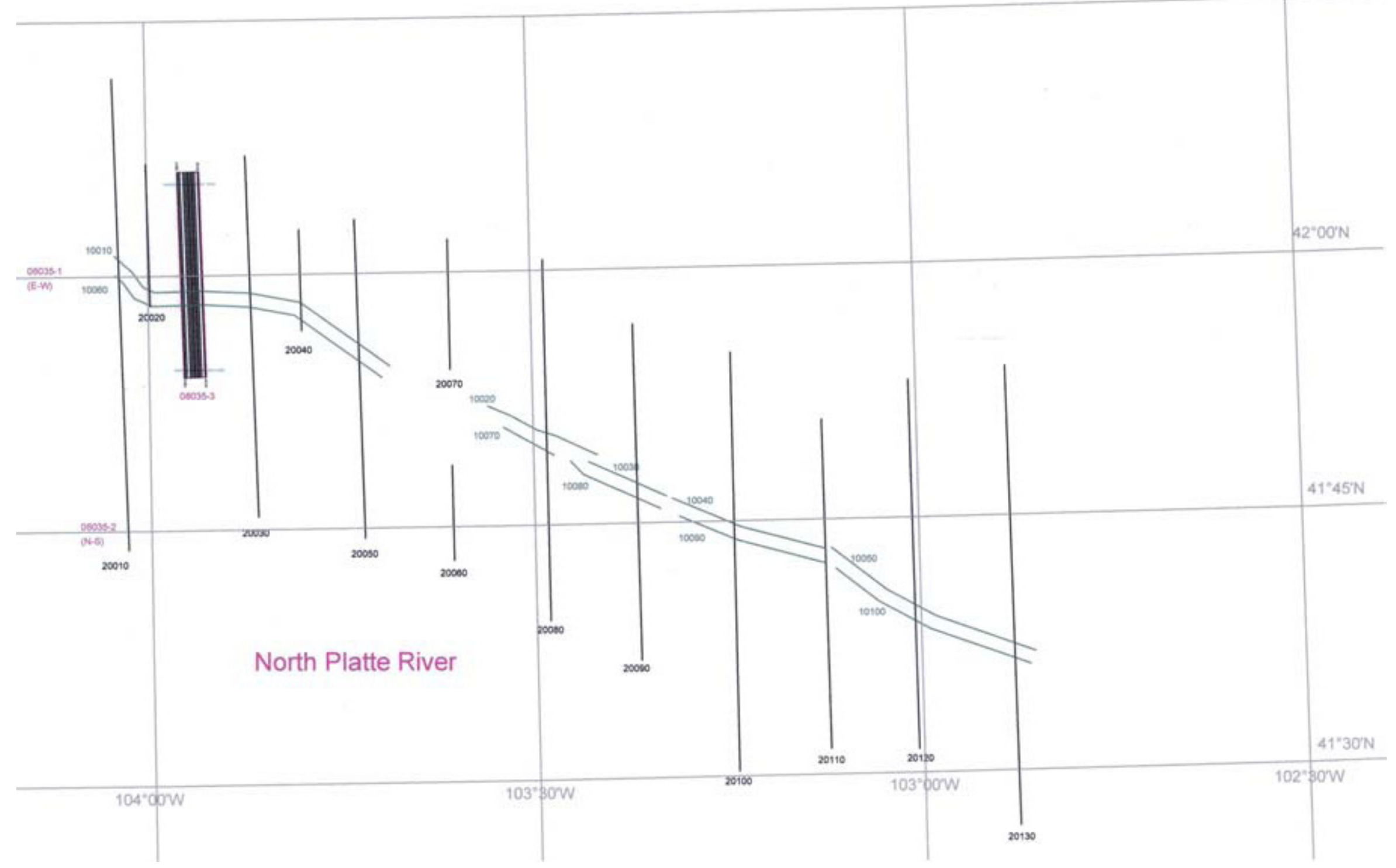


Ш

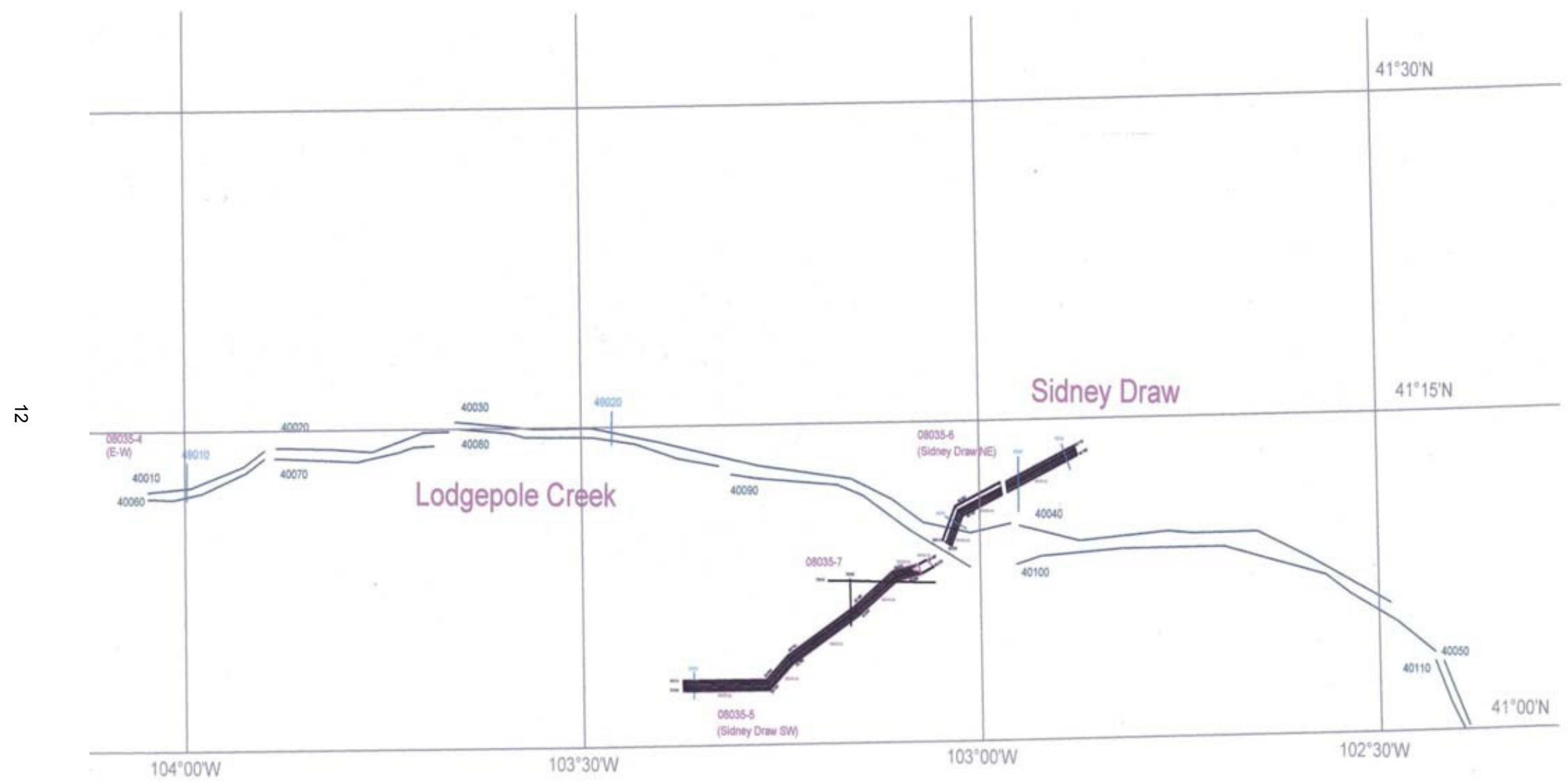


Figure 3. Detailed location maps for HEM survey areas: A) location map for the North Platte River survey and, B) location map for the Lodgepole Creek survey area (adapted from Fugro Airborne, Ltd. report in Appendix 2).

\section{Geophysical Data Overview}

The digital data from the airborne survey was acquired and processed by the contractor, Fugro Airborne Ltd, as described in Appendix 2. The USGS performed quality control for the contractor's data acquisition, processing, and report. In addition, the USGS did some reprocessing of the data to meet specific requirements of this project. Digital data from both the contractor and USGS are included in the present data release. Table 1 contains links to the digital data and a brief description of the files and directories.

Table 1. Digital data organization and description of files and directories

\begin{tabular}{|c|c|}
\hline Directory & Description \\
\hline METADATA & Metadata description of digital data by survey block. \\
\hline$\underline{\text { GIS SURVEY }}$ & $\begin{array}{l}\text { Geographic information consisting of digital raster graphics } \\
\text { (subdirectory DRG) and survey flight lines (FLIGHT_LINES). } \\
\text { The FLIGHT_LINES subdirectory contains subdirectories of } \\
\text { autocad files (CAD_DXF) and shape files (lineSHP). }\end{array}$ \\
\hline$\underline{\text { GRIDS }}$ & $\begin{array}{l}\text { Grids of the electromagnetic and magnetic field data for the } \\
\text { horizontal coplanar coil pairs are in this directory. The grids } \\
\text { are in Geosoft OASIS MONTAJ (http://www.geosoft.com/) } \\
\text { format, a standard of the geophysical industry used in many } \\
\text { map display programs. Subdirectories USGS and FUGRO } \\
\text { contain grids made by the USGS and the contractor. }\end{array}$ \\
\hline LINEDATA & $\begin{array}{l}\text { Flightline data in ascii standard and in the Geosoft OASIS } \\
\text { MONTAJ (http://www.geosoft.com) database in this directory. } \\
\text { The readme file in this directory contains a description of the } \\
\text { channels of the digital line data. }\end{array}$ \\
\hline$\underline{\mathrm{KMZ}}$ & $\begin{array}{l}\text { Plots of flight lines and apparent resistivity maps in key hole } \\
\text { mark up language (extension } \mathrm{kmz} \text { ). These files will plot } \\
\text { directly in Google earth (see report for details). }\end{array}$ \\
\hline PLOTS & $\begin{array}{l}\text { Two subdirectories contain plots of airborne survey data } \\
\text { grids. Subdirectory GEOTIFF contains tiff format plots } \\
\text { (UTM13N. NAD83-projected .tif files) of the grids. } \\
\text { Subdirectory PDF contains plots of the apparent resistivity } \\
\text { data for the NP and SP areas in PDF format. }\end{array}$ \\
\hline$\underline{\text { REPORT6 }}$ & $\begin{array}{l}\text { Directory contains this report, appendix I (poster presented at } \\
\text { the American Geophysical Union } 2008 \text { annual meeting), and } \\
\text { Appendix } 2 \text { (contractor's report). }\end{array}$ \\
\hline
\end{tabular}




\section{Helicopter Electromagnetic and Magnetic Survey}

\section{Method}

Rubin and Hubbard (2005) and Kirsh (2006) give good overviews of geophysical principles and applications for groundwater studies. Airborne geophysical surveys are usually made along regularly spaced flight lines within specified survey areas (fig. 1 and 3 ). Flight lines can be as close as $50 \mathrm{~m}$, though closer spacing is possible in special circumstances. The USGS has generally flown HEM surveys with $200-400-m$ spacing (one-eight to one-quarter mile: Smith and others, 2007), though flight lines with 800-m separation have been used to map regional structures in a carbonate aquifer setting (Smith and others, 2008c). Table 2 gives the flight line specifications for each survey area.

Table 2. Flight line direction and spacing for each survey area. Flight lines are numbered according to block. For example block 1 flight lines are numbered 10010, 10020, and so on

\begin{tabular}{|c|c|c|c|c|c|c|}
\hline Block (number) & $\begin{array}{l}\text { Traverse Line } \\
\text { Azimuth }\end{array}$ & $\begin{array}{l}\text { Tie Line } \\
\text { Azimuth }\end{array}$ & $\begin{array}{l}\text { Traverse Line } \\
\text { Spacing }\end{array}$ & $\begin{array}{l}\text { Traverse Line } \\
\text { Distance }(\mathrm{km})\end{array}$ & $\begin{array}{c}\text { Tie Line } \\
\text { Distance } \\
\quad(\mathrm{km})\end{array}$ & Total $(\mathrm{km})$ \\
\hline N. Platte $E-W(1)$ & Varies E-W & & Along river & 187.27 & & 187.27 \\
\hline N Platte N-S (2) & Varies N-S & & $10 \mathrm{~km}$ & 428.91 & & 428.91 \\
\hline N Platte Block (3) & $358^{\circ} / 178^{\circ}$ & $89^{\circ} / 269^{\circ}$ & $200 \mathrm{~m}$ & 219.75 & 9.09 & 228.84 \\
\hline Lodgepole (4) & Varies E-W & $0^{\circ} / 180^{\circ}$ & Along river & 272.63 & 3.55 & 276.18 \\
\hline Sidney D SW (5) & varies & & $200 \mathrm{~m}$ & 141.89 & 2.58 & 144.47 \\
\hline Sidney D NE (6) & varies & & $200 \mathrm{~m}$ & 85.99 & 7.56 & 93.55 \\
\hline Additional (7) & varies & & $16.02 \mathrm{~km}$ & & & 16.02 \\
\hline TOTAL Distance $(\mathrm{km})$ & & & & $1,352.16$ & 22.78 & $1,375.24$ \\
\hline
\end{tabular}

The main part of the geophysical system is housed in a cylindrical tube or "bird" that is towed beneath the helicopter. In the system flown by Fugro Airborne, Ltd., all of the measurements taken by systems in the "bird" are transmitted via a cable to a processing and digital recording system in the helicopter. Geophysical data measurements, electromagnetic (EM) and total field magnetic are made approximately every three $m$ along the flight line. Figure 4 shows the instrumentation used for HEM surveys which is similar to that used for this survey. 


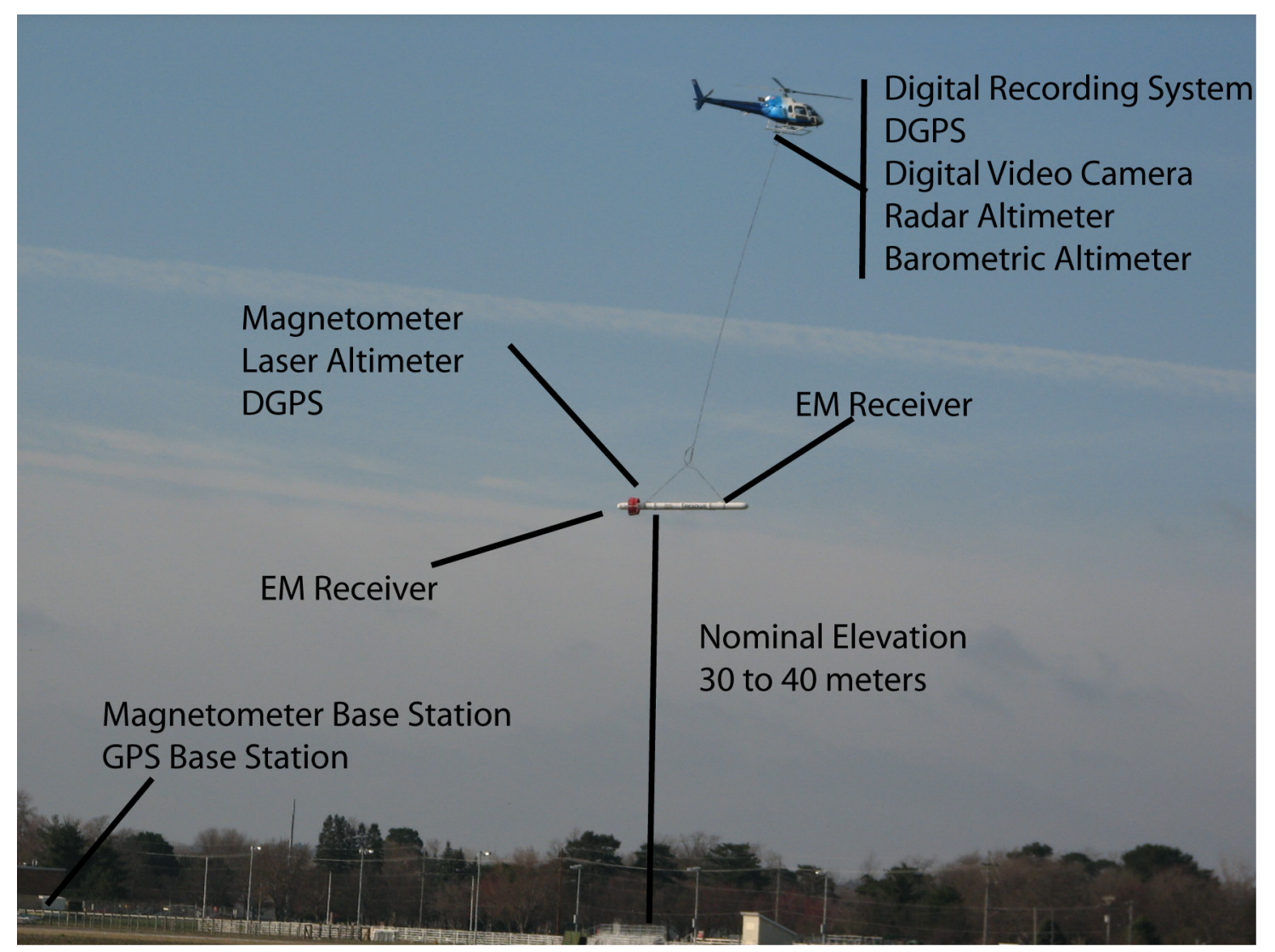

Figure 4. Helicopter-borne RESOLVE@ geophysical system similar that used in the Nebraska survey: Electromagnetic, magnetic, GPS and laser altimeter sensors are housed in a "bird", a cigar-shaped $9 \mathrm{~m}$ long tube, which is kept at about 30-40 m above ground level. Additional altimeters and the navigation system are installed in the helicopter. The base station records the total magnetic field variations (diurnal) during the survey.

\section{HEM Measurements}

The principles of HEM methods are well summarized by Paine and Minty (2005) and Siemon (2006). The RESOLVE ${ }^{\odot}$ HEM system flown by Fugro Airborne Ltd. is described in detail in the contractor's report given in Appendix 2. The EM measurements are made using six coil pairs that measure EM signals at separate frequencies from about $400 \mathrm{~Hz}$ to about $140,000 \mathrm{~Hz}(140 \mathrm{kHz})$. Five of the coil pairs were oriented in a horizontal, coplanar position and one of the coil pairs was oriented in a vertical, coaxial position. The specific frequencies, separation, and orientation of the coil pairs are given in table 4. 
Table 3. Frequencies and measurement sensitivities for the HEM survey. The coil pair separation is 7.9 meters for all except for the $3300 \mathrm{~Hz}$ coil-pair which is 9.0 meters.

\begin{tabular}{|c|c|c|c|}
\hline Coil configuration & $\begin{array}{c}\text { Nominal } \\
\text { frequency } \\
\text { (hertz) }\end{array}$ & $\begin{array}{c}\text { Actual } \\
\text { frequency } \\
\text { (hertz) }\end{array}$ & $\begin{array}{c}\text { Sensitivity (parts per } \\
\text { million) }\end{array}$ \\
\hline Coplanar & 400 & 380 & 0.12 \\
\hline Coplanar & 1,800 & 1,766 & 0.12 \\
\hline Coaxial & 3,300 & 3,345 & 0.12 \\
\hline Coplanar & 8,200 & 8,171 & 0.24 \\
\hline Coplanar & 40,000 & 41,020 & 0.60 \\
\hline Coplanar & 140,000 & 129,550 & \\
\hline
\end{tabular}

The EM measurements made approximately every $3 \mathrm{~m}$ (10 feet) along flight lines are reduced to apparent resistivity values as described in the contractor's report (Appendix 2). One important consideration of the HEM earth subsurface imaging is that the depth of imaging is dependent on the frequency of the EM signal and resistivity of the earth. One estimate of the depth of exploration (depth of mapping) for the frequencies used in the RESOLVE@ system is shown in Figure 5. In this figure, the depth of exploration is defined as 0.5 of the skin depth (the point at which a plane electromagnetic wave has attenuated to 37 percent of the initial amplitude). The depths-of-exploration estimates shown in igure 5 are conservative, since one skin depth generally is considered to be the depth limit of HEM measurements (Fraser, 1978). Generally, at the highest frequency, depths of exploration are just a few meters. At the lowest frequency, $400 \mathrm{~Hz}$, the depth of exploration may be around $80-\mathrm{m}$. This aspect of HEM resistivity measurements is the basic principle that allows depth images to be constructed. 


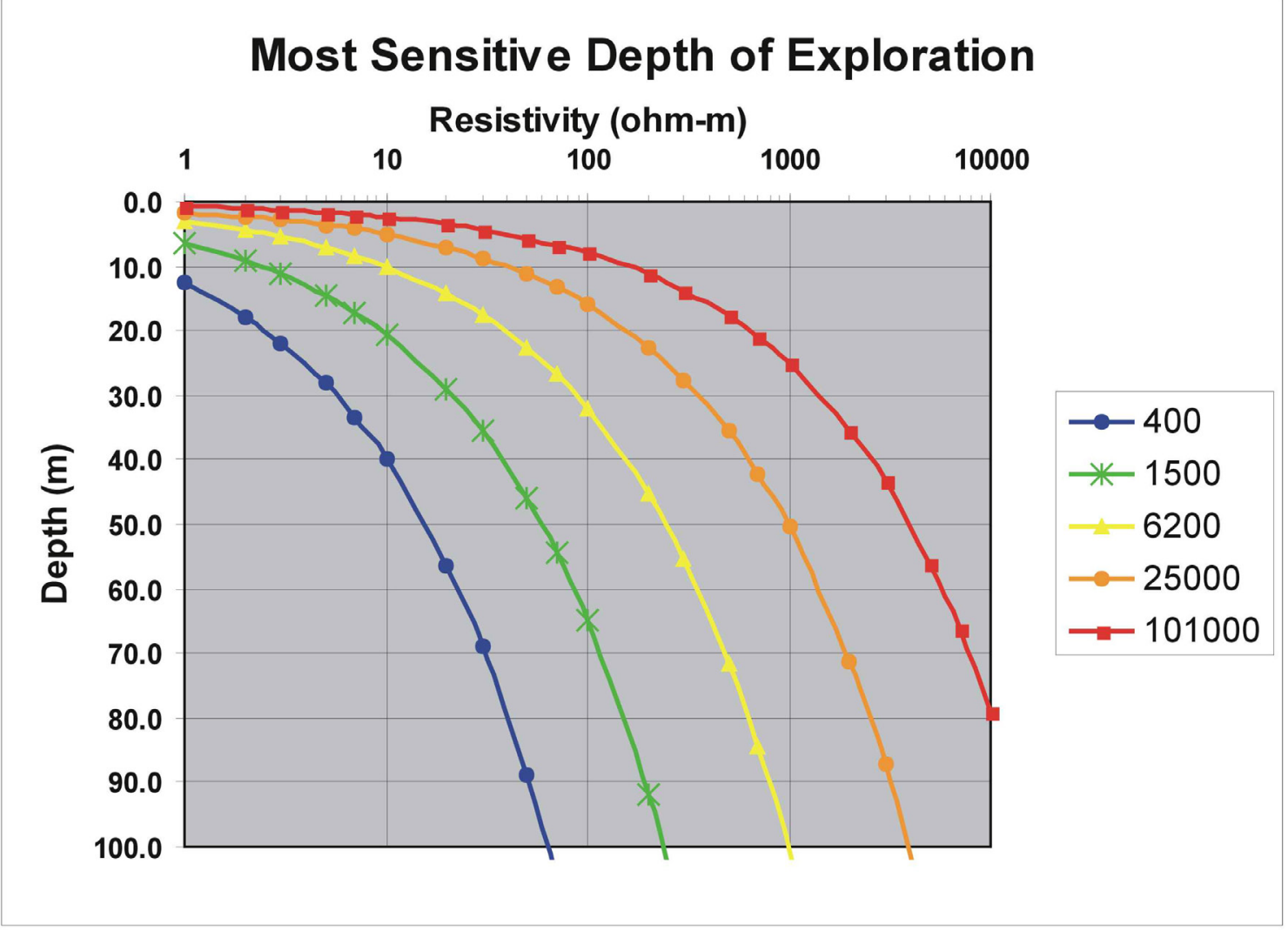

Figure 5. Depth of penetration or imaging as a function of frequency and earth resistivity for the RESOLVE@ system (G. Hodges, Fugro Airborne Ltd., 2004, written comm.). Frequencies, in hertz, are given for each colored line on the right.

The EM signals are recorded for each frequency as in-phase and quadrature (outof-phase) where the phase is referenced to the transmitted signal. The EM signals are post-processed to apparent resistivity for each frequency and a corresponding apparent depth as described in Appendix 2 and by Fraser (1978). The apparent resistivity is, as the name implies, not the intrinsic electrical resistivity of the earth but an estimated resistivity value based on assumptions of the measurement and of a homogeneous earth (Fraser, 1978). Estimates of the intrinsic resistivity and its subsurface distribution are obtained through a variety of imaging methods that are described by Hodges (2004) and Seimon (2006). The differential resistivity and depth transformation (Huang and Fraser, 1996) is one simple depth imaging method that has proven effective for HEM survey data (Smith and others, 2003). Both the apparent resistivity and differential data are given in the digital line data files (see readme file in LINEDATA directory).

An important part of the data processing is leveling the EM signals for system drift and calibrations. The specific steps used in the data processing are described in Appendix 2. The digital line data gives the raw in-phase and quadrature data and the processed 
data from which the apparent resistivites are computed. The final leveled data is also given. The raw EM data included in the data base can be used for reprocessing.

\section{Total Magnetic Field Measurements}

The magnetic system measured the Earth's total field to an accuracy of 0.01 nanoTesla (nT). The magnetic field consists of the Earth's main magnetic field and the local magnetic field created by sources within the crust and ferromagnetic metallic sources at the surface. The total field measurements are influenced by short term variations in the magnetic field which are independent of local sources and are caused mainly by solar activity. A total magnetic field base station, set up by the contractor near the base of operations, is used to record these short term variations in the earth's total magnetic field which subtracted from the measurements made during the survey.

The spatial variation of the earth's main magnetic field is defined by the International Geomagnetic Reference Field or IGRF. The contractor also processed the total magnetic field measurements along the flight lines to remove the IGRF variations. Sharma (2002) describes the basic principles of the main magnetic field removal from magnetometer measurements.

\section{Ancillary Measurements}

The airborne electromagnetic system also monitors $60 \mathrm{~Hz}$ signals in coaxial and coplanar coil configurations. The data are given as CXPL CPPL channels in the line database (LINEDATA). The data are given as arbitrary voltage levels, which generally increase over power lines. The electrical expression of power lines in the EM data and apparent resistivity is quite variable due to a number of factors such as the size of the line, how well it is "grounded", and the electrical resistivity of the earth. In general, the infrastructure around urban development, pipe lines, rail lines, transmission towers, and power lines along major roads produce electrical or cultural noise level that result in high $60 \mathrm{~Hz}$ signals. The EM signals in these monitors have not been calibrated and are intended to be used as a indication of where cultural noise may affect the EM data.

Positioning measurements of the "bird" and the helicopter are critical in processing and making accurate maps. Location data from GPS systems in both the "bird" and helicopter are given in the files in the LINEDATA directory. Elevation data from the laser altimeter on the bird as well as from the radar and barometric altimeters on the helicopter are given in the LINEDATA files. An important aspect of the contractor's data processing is that the elevation data are given in the WGS84 Spheroid and have not been reduced to an ellipsoid. The contractor's report explains that additional processing needed to do this data reduction was not part of the USGS contract. Care must be taken that the projection conventions are compatible when the elevation data from the HEM survey are used with other digital data sets, such as digital elevations.

\section{Digital Data}

Digital data is given in the directories described in Table 1. The following describes the digital data in each subdirectory. 


\section{Metadata}

The metadata directory contains files that describe the (Fig. 1 and 3). These survey blocks are the boundaries for line data, digital grids, and plots. The metadata also describes the projection (NAD83 UTM14 m) used for all of the digital plots.

\section{GIS Data}

The GIS directory contains various files that may be useful in map preparation. The flight line location files are in dxf format (AUTOCAD) and as ESRI shape files (.shp and ancillary files).

\section{Grids}

Flight line data are interpolated onto a regular grid (gridded) to produce map plots. One of the challenges of gridding flight line data from airborne geophysical surveys is that the spacing between flight lines is much greater than the sampling along the line (a few meters). Specialized gridding methods have been developed to deal with this aspect of processing flight line data from airborne geophysical surveys (Smith and O'Connell, 2005). The contractor has used a modified Akima spline method (Appendix 2, and Fugro technical note:

http://www.fugroairborne.com/resources/technical notes/time domain em/pdfs/Akima te nsion III.pdf). The contractor grids are given in the GRIDS directory in the FUGRO subdirectory. These grids have not been modified. The nomenclature for the grid names is given in the readme.txt file.

An alternate gridding method is the minimum curvature method implemented by Webring (1981) for geophysical airborne data. This gridding method is used in the GEOSOFT OASIS MONTAJ program (Geosoft, 2006) (http://www.geosoft.com/resources/papers/pdfs/topicsingriddingworkshop.pdf). We have used this algorithm to produce grids from selected channels of the flight line data. These grids can be found in the subdirectory USGS. The grid cell size was $75 \mathrm{~m}$. File naming convention is given in the readme.txt file. The USGS grids also include the magnetic data, digital elevation, and powerline monitor data. These grids have $75 \mathrm{~m}$ cell size. The grids can be viewed with free software distributed by GEOSOFT

(http://www.geosoft.com/pinfo/oasismontaj/free/montajviewer.asp). Plug-ins for various mapping software packages can be found on the GEOSOFT Web site (http://www.geosoft.com/downloads/). Plots produced from the grid files are described below. 
The grids can be imported into ESRI ArcMap applications with a plug-in provided by GEOSOFT (http://www.geosoft.com/resources/releasenotes/plugins/arcG/Splugin.asp). A sample display of one such plot in ArcMap is shown in figure 6. Color scale bars can be imported to match those of the GEOTIFF maps. The grids may need to be given specific projection information (NAD83 UTM13N) depending on the base maps that are used.

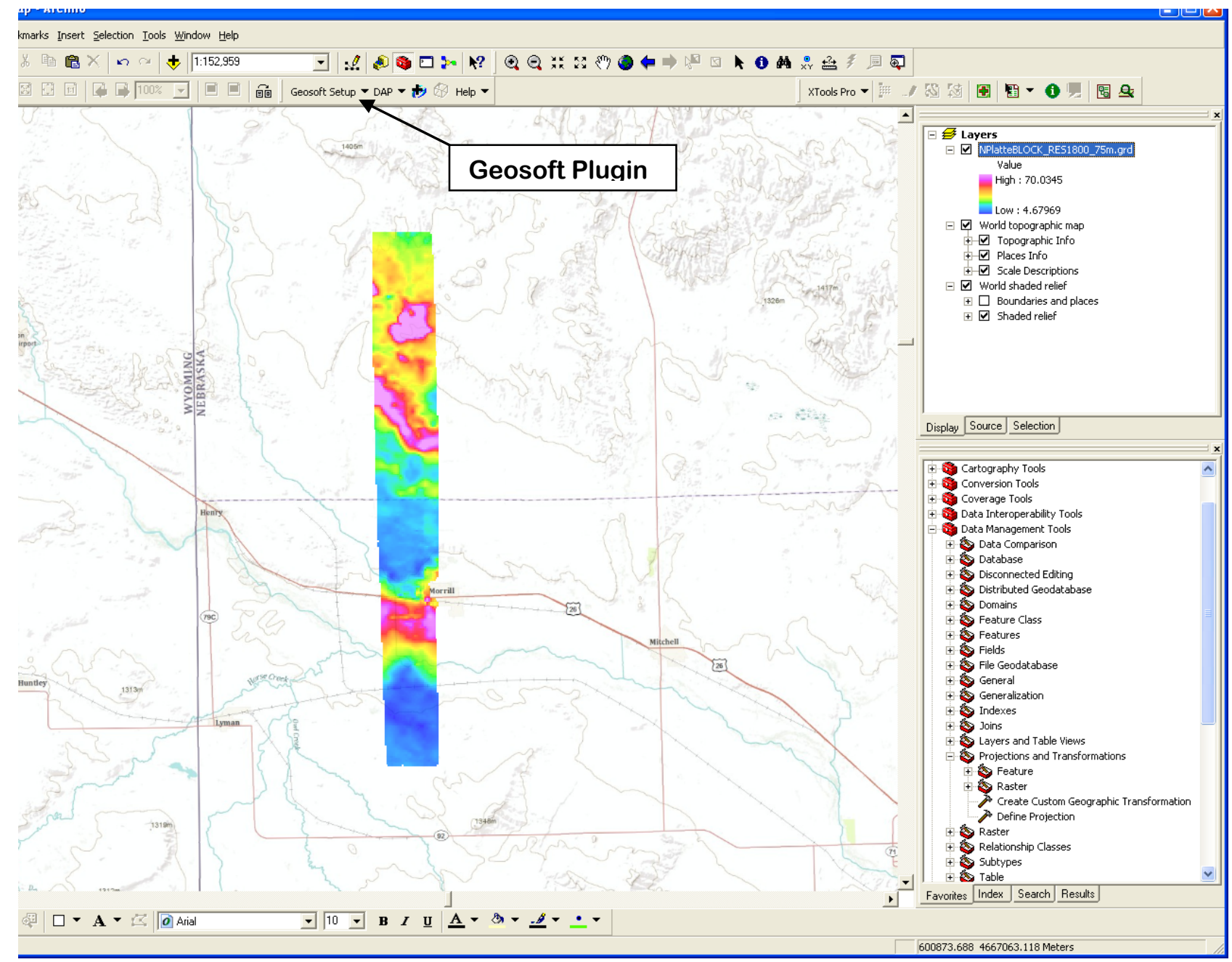

Figure 6 Screenshot of ArcMap plot of GEOSOFT grid for the Morrill Block. Note the GEOSOFT plug-in is displayed in the toolbar. The background topographic relief map is displayed using data added by internet servers. The display in the lower right shows the projection tool that might be needed to properly define the projection of the grid. 


\section{Plots}

The USGS has produced plots (in PLOTS directory) of the gridded data described above (.pdf files in the PDF sub-directory) and geo-referenced in .tif format in the GEOTIFF sub-directory). The projection used for the geotiff plots is the same as for the grid files, NAD83 UTM13N. The plot files have been produced with a color scale common to all frequencies for each survey area. Thus the colors for apparent resistivity maps can be directly compared between frequencies. Generally the apparent resistivity is higher by about 75 ohm meters for the North Platte River area, so a color scale with a slightly different range has been used than for the Lodgepole Creek area. The color scale gives high resistivity as warm colors (reds) and low resistivity as cool colors (blues).

\section{Digital Flight Line Data}

The flight line data for each area is given in the directory LINEDATA. The files are given in ascii format with column headings as described in the readme file. The contractors report in Appendix 2 also describes the digital flight line data.

\section{Keyhole Markup Language Files}

The keyhole markup language $(\mathrm{KML})$ is a programming language used to present geographic map information on the world wide web. According to Wikipedia (http://en.wikipedia.org/wiki/Kml) KML was developed for use with Google Earth, which was originally named Keyhole Earth Viewer. It was created by Keyhole, Inc, which was acquired by Google in 2004. The name "Keyhole" is homage to the Key Hole reconnaissance satellites, the original eye-in-the-sky military reconnaissance system first launched in 1976. KML files are often distributed as KMZ files which are compressed or zipped KML files. KMZ files are used to display geographic data in an Earth browser such as Google Earth (GE), Google Maps, and in ESRI Arcviewer.

Presentation of HEM data at a 2008 public meeting of the NPNRD showed that there was interest in being able to show geophysical flight lines and data in Google Earth using . kmz files. Consequently a set of files in this format have been included in this report. In the year that has passed since that meeting there has been increasing interest in use of GE as a platform for display of earth science maps and data. A special session at the 2008 American Geophysical Union and the keynote address of the meeting discussed use of Google Earth in earth and planetary sciences (Jones, 2008).

A user's guide to Google Earth can be found at the following hyperlink: (http://earth.google.com/int//en/userguide/v5/). The display of flight lines and data can be shown by clicking the files in the KMZ directory (if a link has been established for this file type) or by opening the .kmz file in GE. A sample image of the GE displays are shown on the cover of this report and for a sample area near Sidney, Nebraska in Figure 6. 


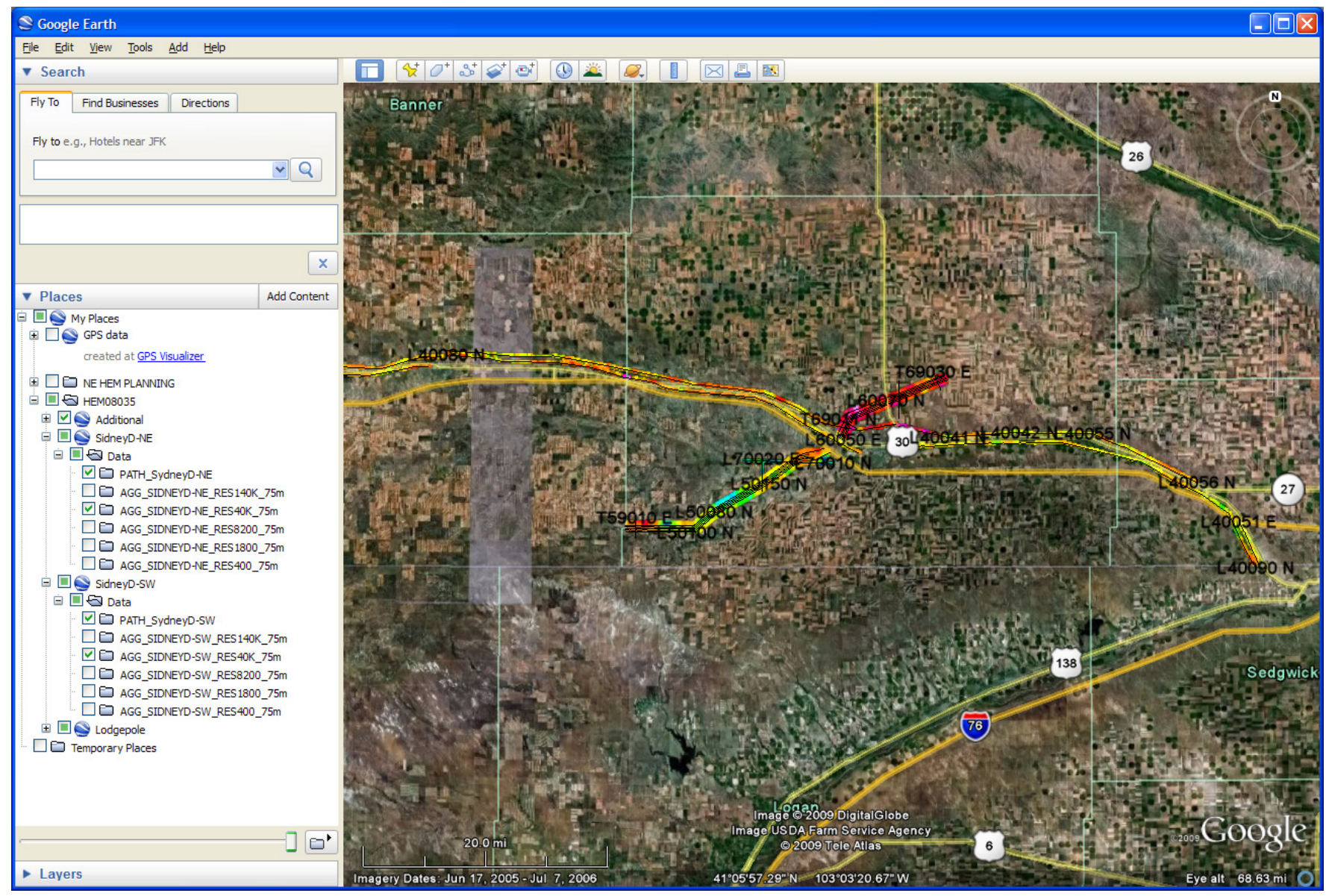

Figure 7. Screen capture of a Google Earth map for the HEM survey in Sidney, Nebraska, area. The data shown is the apparent resistivity map at $40,000 \mathrm{~Hz}$. Black lines are flight lines with selected flight line numbers shown. Note that in the panel on the left of the display, various layers can be turned on and off and their transparency adjusted.

\section{Acknowledgments}

The authors would like to thank Ron Cacek, Manager, NPNRD, and Rod Horn, Manager, SPNRD, for coordinating financial and material support of the hydrogeophysical program. In particular the NPNRD took the lead in contracting the airborne geophysical survey. The Nebraska Environmental Trust Fund provided partial funding for the airborne geophysical project. We also wish to recognize Kay Grote and Don Ogle, public relations and education officers for the NPNRD and SPNRD for help in announcements and coordination with media and public safety offices. Roy Lyles (NP), coordinated field efforts. Jeff Sprock (NP) and Kyle Liebig (SP) provided insight for developing useful formats for the geophysical data to facilitate applications to GIS aspects of the NRD programs. Michelle Johnson provided USGS GIS support through the planning and data release parts of the project. Jonah Sullivan aided in the preparation of geophysical grids and images. The authors would also like to thank the following personnel of Fugro Airborne Ltd., for their insight and technical support with organizing, collecting, 
processing, and describing the HEM data: Andy Semple, Supervisor Field Operators, I; Darren Hamill, Field Geophysicist/Crew Leader, Chris Tucker Pilot (Great Slave Helicopters Ltd.), Russell Imrie, data post-processing Geophysicist, Richardo White, Geophysical data processor, Lyn Vanderstarren, drafting and geophysical flight line layouts.

\section{References Cited}

Cannia, J.C., Woodward, D., and Cast, L.D., 2006, Hydrostratigraphic units and aquifer characterization report: available at Cooperative Hydrologic Study COHYST, 126 p. http://cohyst.dnr.ne.gov/document/dc012hydro_aquifer_022406.pdf (accessed June 2, 2009).

Cannia, J.C., Abraham, J.A., Smith, B.D., Steele, G.V., and Korus, J.T., 2007, Preliminary results of hydrogeological framework studies of surface water-Ground water systems in eastern Nebraska using airborne and ground geophysics: Geological Society of America Abstracts with Programs, v. 39, no. 6, p. 162.

Fraser, D.C., 1978, Resistivity mapping with an airborne multicoil electromagnetic system: Geophysics, v. 43, p. 144-172.

Geosoft Inc., 2006, Oasis Montaj Users Manual Version 7.1: 297 p. accessed June 2, 2009 , at www.geosoft.com.

Hodges, G., 2004, Practical inversions for helicopter electromagnetic data, in Proccedings of the Symposium on the Application of Geophysics to Engineering and Environmental Problems: Environmental and Engineering Geophysical Society, 10 p. (available at http://www.fugroairborne.com.au/resources/technical_papers/airborne_em/pr actical_HEM_inversions.html, accessed June 2, 2009), 4 p.

Huang, H., and Fraser, D.C., 1996, The differential parameter method for muiltifrequency airborne resistivity mapping: Geophysics, v. 55, p. 1,327-1,337

Jones, M., 2008, Frontiers of Geophysics Lecture: The spread of scientific knowledge from the Royal Society to Google Earth and beyond: Presented American Geophysical Union Annual meeting, San Francisco (http://www.agu.org/webcast/fm08/).

Kirsch, R., 2006, Groundwater geophysics—A tool for hydrogeology: Springer-Verlag, Heidelberg, $489 \mathrm{p}$.

Paine, J. G., and Minty, B. R. S., 2005, Chapter 11-Airborne hydrogeophysics, in Rubin, Yoram, and Hubbard, S.S., eds., Hydrogeophysics: Dordrecht, The Netherlands, Springer, Water Science and Technology Library, v. 50, p. 333-357. 
Reid, J.E., Pfaffling, A., and Vrbancich, J., 2006, Airborne electromagnetic footprints in 1D earths: Geophysics, v. 71, no. 2, p. 63-72.

Rubin, Y., and Hubbard, S.S., 2005, Hydrogeophysics, Dordrecht, Dordrecht, The Netherlands, Springer, Water Science and Technology Library, v. 50, 523 p.

Sharma, P.V., 2002 (reprinted), Environmental and engineering geophysics: Cambridge, England, Cambridge University Press, $472 \mathrm{p}$.

Siemon, B., 2006, Electromagnetic methods-Frequency domain-Airborne techniques, in Kirsch, R., ed., Groundwater Geophysics-A Tool for Hydrogeology: SpringerVerlag, Heidelberg, p. 155-170.

Smith, B.D., Irvine, R., Blome, C.D., Clark, A.K., and Smith, D.V., 2003, Preliminary results, helicopter electromagnetic and magnetic survey of the Seco Creek area, Medina and Uvalde Counties, Texas: Proceedings for the Symposium on the Application of Geophysics to Environmental and Engineering Problems, San Antonio, Texas, $15 \mathrm{p}$.

Smith, B.D., Thamke, J.N., Cain, M.J., Tyrrell, C., and Hill, P.L., 2006, Helicopter electromagnetic and magnetic survey maps and data, East Poplar oil field area, August 2004, Fort Peck Indian Reservation, northeastern Montana: U.S. Geological Survey Open-File Report 2006-1216, 23 p., 1 plate.

Smith, B.D., Grauch, V.J.S., McCafferty, A.E., Smith, D.V., Rodriguez, B.R., Pool, D.R., Deszcz-Pan, M., and Labson, V.F., 2007, Airborne electromagnetic and magnetic surveys for ground-water resources-A decade of study by the U.S. Geological Survey, in "Proceedings of Exploration 07: Fifth Decennial International Conference on Mineral Exploration", Milkereit, B., ed., Decennial Mineral Exploration Conferences, Toronto, Canada, p. 895-899.

Smith, B.D., Abraham, J.D., Cannia, J.C., Steele, G.V., and Hill, P., 2008a, Helicopter electromagnetic and magnetic geophysical survey data, Oakland, Ashland, and Firth study areas, eastern Nebraska, March 2007: U.S. Geological Survey OpenFile Report 2008-1018, 31 p., 1 plate.

Smith, B.D., Abraham, J.A., Cannia, J.C., Steele, G.V., and Peterson, S.M., 2008b, Helicopter electromagnetic surveys for hydrological framework studies in Nebraska, Eos Transactions American Geophysical Union, v. 89, no. 53, Fall Meeting Supplement, Abstract NS43B-1190, $1 \mathrm{p}$.

Smith, B.D., Blome, C.D., Smith, D.V., Scheirer, D.D., Deszcz-Pan, M., 2008c, Geophysical surveys to characterize the hydrogeology of the Arbuckle Uplift, southcentral Oklahoma: Symposium on Environmental and Engineering Geophysics, Philadelphia, 2008 Annual Meeting Proceedings, p. 539-548. 
Smith, R.S., and O'Connell, M.D., 2005, Interpolation and gridding of aliased geophysical data using constrained anisotropic diffusion to enhance trends: Geophysics, v. 70, no. 5, p 121-127.

Steele, G.V., Sibray, S.S., and Quondt, K.A., 2007, Evaluation of ground water near Sidney, Nebraska, 2004-05: U.S. Geological Survey Scientific Investigations Report 2007-5086, 54 p.

Weeks, J.B., Gutentag, E.D., Heimes, F.J., and Luckey, R.R., 1988, Summary of the High Plains regional aquifer-system analysis in parts of Colorado, Kansas, Nebraska, New Mexico, Oklahoma, South Dakota, Texas, and Wyoming: U.S. Geological Survey Professional Paper 1400-A, $30 \mathrm{p}$.

Webring, Michael, 1981, MINC—A gridding program based on minimum curvature: U.S. Geological Survey Open-File Report 81-1224, 43 p.

Wikipedia, The Free Encyclopedia, (accessed June 2009), Keyhole Markup Language: http://en.wikipedia.org/wiki/Kml.

Won, I.J., 1990, Diagnosing the earth-Ground-water monitoring review: National Ground Water Association, Summer 1990, 2 p. 


\section{Appendix 1: American Geophysical Union Poster Helicopter Electromagnetic Survey for Hydrological Framework Studies in Nebraska (Smith and others, 2008b)}

The poster is provided in the REPORTS directory as HEM_AGU_poster_20081209.pdf. 


\section{Appendix 2: Fugro Airborne Ltd. Geophysical Report}

The contractor's report (08034rep.pdf) is given in the REPORTS directory. 